\title{
Avellaneda, Mercedes. Guaraníes, criollos y jesuitas. Luchas de poder en las revoluciones comuneras del Paraguay. Siglos XVII y XVIII
}

Asunción, Academia Paraguaya de la Historia y Tiempo de Historia, 2014, 297 páginas.

11

uaraníes, criollos y jesuitas" es el fruto de una investigación etnohistórica, pero también es producto de una perspectiva novedosa y distinta sobre un tema clásico de historiografía argentina: el desarrollo del complejo de las reducciones indígenas tupí- guaraní. En esta obra, Avellaneda intenta abordar en clave política las disputas de poder que se desencadenaron en el territorio paraguayo, para así lograr comprender cuál es el rol y el comportamiento de los jesuitas, los pueblos guaraníes y los criollos asunceños, en especial los vecinos encomenderos, todos actores fundamentales en aquel territorio fronterizo.

El libro ubica rápidamente al lector en el espacio paraguayo, en la zona poblada por los grupos tupi-guaraní, y logra explotar con lucidez la relevancia geopolítica de la región. Nos sitúa de frente a una situación fronteriza, entre dos imperios que disputan los límites de sus respectivas jurisdicciones y generan fluctuaciones constantes y cambios importantes en los actores sociales y en las relaciones que estos mantienen. En este sentido, Avellaneda se involucra con la labor histórica para analizar un proceso en el correr de dos siglos distintos, el XVII y el XVIII. Por otra parte, el desarrollo del proceso en el tiempo requiere de un constante ordenamiento espacial. Para ello, la explicación se complementa con un gran trabajo cartográfico que da luz a la obra y proporciona nuevos medios de entendimiento para el lector. En especial, se grafican las expansiones y las retracciones de las misiones jesuíticas, así como su desplazamiento sobre las cuencas del rio Paraná y Uruguay. También se recurre en este libro a la utilización de las escasas estadísticas que se pueden extraer de las fuentes, en especial para analizar las consecuencias de las Guerras Comuneras en las misiones y en la alianza jesuítica-guaraní. Se puede ver, asimismo, un esfuerzo por sistematizar datos cuantitativos que complejizan la explicación y proporcionan un gran pilar empírico. Además, al final del libro, se anexan cuatro censos de distintas misiones que se han extraído de las distintas Cartas Anuas de cada misión.

La obra analiza un proceso en el cual están enfrentadas, por un lado, la alianza jesuítico-guaraní, la cual contaba incluso con poder de fuego, y además fue apoyada la mayor parte del tiempo por la corona hispana y por el otro, la comunidad criolla asunceña, que asumía un decidido perfil militar, relacionado con la situación geográfica de frontera. Ambas, entonces, son reconocidas como polos de poder político y militar. De tal manera, ambas son el recorrido obligatorio que debe analizar Avellaneda para desembocar en el fermento que llevó al momento de estallido social durante la llamada 'Revolución de los Comuneros'. Solo así se puede comprender el poder que adquirió el Cabildo en Asunción, en tanto institución representativa de los criollos, que no solamente disputó con la Compañía lo que 
consideraba sus derechos de encomienda, sino que también desafió a la Audiencia de Charcas y a las milicias reales. Esta gran revuelta es el proceso analizado y diseccionado a la perfección por Avellaneda, necesario para lograr adentrarnos en la lógica de un conflicto en extremo desordenado y caótico. Para ello, se apela a la heurística histórica porque se subdivide la revuelta, cuya duración es de catorce años, en tres subprocesos. Este tipo de labor requiere de un gran trabajo empírico al que se llega, en su mayor parte, mediante fuentes directas elaboradas por los actores protagonistas, a excepción de los guaraníes que aquí son abordados por fuentes indirectas. Queda expuesto entonces que la materia prima, sustancia del trabajo, proviene de fuentes administrativas y judiciales. Quizá, en su mayoría éstas se produjeron durante los conflictos en cada una de las instituciones, lo que exige un gran trabajo de triangulación y contrastación.

Avellaneda logra toda su explicación en derredor al factor 'conflicto'. En parte derrumba el viejo mito del orden solemne en la evangelización del 'buen salvaje' y de las etnias guaraníes, que, en su explicación, son reconocidas como actores sociales capaces de negociar su seguridad y resguardo aceptando las reducciones. La conformación de milicias guaraníes y su lucha violenta contra españoles, bandeirantes y demás etnias de indios infieles le concede lógica a la aceptación negociada de la evangelización. En este sentido, los jesuitas dejan de ser meros agentes evangelizadores y su labor política los convierte en actores capaces de explotar las contradicciones de la frontera sirviéndose de los favores de la corona. De tal manera, la monarquía hispana intentó controlar y disminuir el poder de los criollos encomenderos colocándoles competidores en el reparto de la mano de obra y en la conformación de los mercados.

Este libro recorre tensiones constantes y desestabilizaciones de poder que transforman el entramado político de la región. Sin embargo, lo que está en juego verdaderamente son los derechos y prerrogativas que conceden poder sobre los recursos económicos. La autora lo demuestra al comprobar la correlación entre los estallidos de conflicto y las crisis económicas que azotan principalmente a los encomenderos. En este sentido, se vuelve reveladora su labor etnohistórica ya que conjuga metodologías y logra borrar fronteras entre las ciencias sociales. Esta estrategia es capital para lograr la múltiple comprensión de los procesos sociales.

Para finalizar debe remarcarse que este trabajo se inserta en el interior de las nuevas corrientes historiográficas que problematizan, con rigor científico, la labor jesuita en las misiones. De modo que la historiografía actual realiza una evaluación de la actuación del trabajo de los misioneros que se escapa del boceto de la descripción apologética realizada por ciertos círculos de historiadores jesuitas o cercanos a la Compañía. Las fuentes ahora, además de que se han multiplicado, son analizadas de forma crítica por las distintas ramas de las ciencias sociales. Sin embargo, ni los estudios etnológicos, ni los estudios históricos fueron capaces de analizar en conjunto todos los actores de la región, así como no lograron analizar las relaciones dinámicas propias del territorio fronterizo en un periodo tan extendido de tiempo. Por eso, el aporte indudable de esta obra es el de encontrar la presentación y relación de todos los actores en disputa, así como el indudable éxito en armonizar las estrategias metodológicas de las ciencias sociales para dar luz a un tema tan complejo como opaco.

Enzo Martínez

Departamento de Historia, Facultad de Ciencias Humanas Universidad Nacional de La Pampa 